\title{
Effects of low back pain on balance performance in elderly people: a systematic review and meta-analysis
}

\author{
Le Ge', Chuhuai Wang ${ }^{1 *}$, Haohan Zhou ${ }^{2}$, Qiuhua Yu ${ }^{1}$ and Xin Li ${ }^{1}$
}

\begin{abstract}
Background: Research suggests that individuals with low back pain (LBP) may have poorer motor control compared to their healthy counterparts. However, the sample population of almost $90 \%$ of related articles are young and middle-aged people. There is still a lack of a systematic review about the balance performance of elderly people with low back pain. This study aimed to conduct a systematic review and meta-analysis to understand the effects of LBP on balance performance in elderly people.

Methods: This systematic review and meta-analysis included a comprehensive search of PubMed, Embase, and Cochrane Library databases for full-text articles published before January 2020. We included the articles that 1) investigated the elderly people with LBP; 2 ) assessed balance performance with any quantifiable clinical assessment or measurement tool and during static or dynamic activity; 3) were original research. Two independent reviewers screened the relevant articles, and disagreements were resolved by a third reviewer.

Results: Thirteen case-control studies comparing balance performance parameters between LBP and healthy subjects were included. The experimental group (LBP group) was associated with significantly larger area of centre of pressure movement $(P<0.001)$, higher velocity of centre of pressure sway in the anteroposterior and mediolateral directions $(P=0.01$ and $P=0.02$, respectively), longer path length in the anteroposterior direction $(P<$ 0.001), slower walking speed $(P=0.05)$, and longer timed up and go test time $(P=0.004)$ than the control group.
\end{abstract}

Conclusion: The results showed that balance performance was impaired in elderly people with LBP. We should pay more attention to the balance control of elderly people with LBP.

Keywords: Low back pain, Balance performance, Elderly people

\section{Background}

It was reported that the world's population aged $\geq 60$ years will triple by 2050 [1]. Rapidly growing aging populations have increased the prevalence of diseases such as musculoskeletal pain. The reported prevalence of muscular and skeletal pain is $65-85 \%$ in elderly people $[2,3], 36-70 \%$ of which had LBP $[3,4]$. Low back pain was the most

\footnotetext{
* Correspondence: wangchuh@mail.sysu.edu.cn

'Department of Rehabilitation Medicine, The First Affiliated Hospital, Sun Yat-sen University, Zhongshan Road, Guangzhou 510080, Guangdong Province, China

Full list of author information is available at the end of the article
}

common health problem among older adults, results in pain and disability [5]. Moreover, elderly people with LBP are often underreported and inadequately provided with treatment [6]. Untreated or undertreated older individuals with LBP may experience sleep disturbances, limitations to their social and recreational activities, psychological distress, decreased cognition, rapid deterioration of functional ability, and falls subsequently causing great burdens on family and society [7-9].

Balance, which is fundamental to activities of daily living, is impaired in the patients with LBP [10]. Most

C C The Author(s). 2021 Open Access This article is licensed under a Creative Commons Attribution 4.0 International License, which permits use, sharing, adaptation, distribution and reproduction in any medium or format, as long as you give appropriate credit to the original author(s) and the source, provide a link to the Creative Commons licence, and indicate if changes were made. The images or other third party material in this article are included in the article's Creative Commons licence, unless indicated otherwise in a credit line to the material. If material is not included in the article's Creative Commons licence and your intended use is not permitted by statutory regulation or exceeds the permitted use, you will need to obtain permission directly from the copyright holder. To view a copy of this licence, visit http://creativecommons.org/licenses/by/4.0/ The Creative Commons Public Domain Dedication waiver (http://creativecommons.org/publicdomain/zero/1.0/) applies to the data made available in this article, unless otherwise stated in a credit line to the data. 
functional tasks in daily life require balance control in the horizontal and vertical directions. Impaired balance is associated with poor motor control, the ability for one to maintain their balance and body orientation during locomotion [11]. Previous studies demonstrated that patients with LBP may have impaired motor control [1214], which would further affect their balance performance and motor behaviour.

Balance dysfunction in the aging population is based on knowledge of the normal aging processes, loss of sensory elements, and loss of musculoskeletal function [15]. Balance performance declines with age due to biological changes (e.g. mobility, physical inactivity), which in turn could lead to falls $[16,17]$. LBP is known to be an independent risk factor for recurrent falls in older women [18].

What is the effect of aging combined with LBP? Here we aimed to conduct a systematic review and metaanalysis to understand the effects of low back pain in elderly people with the ultimate goal of providing better clinical research and treatment guidelines.

\section{Methods}

\section{Literature search strategy}

This review was conducted according to the guidelines outlined in the Preferred Reporting Items for Systematic Reviews and Meta-analysis (PRISMA) statement [19]. Two independent investigators screened the titles and abstracts of the retrieved studies to identify those appropriate for full-text review. Subsequently, they independently assessed the papers in full to identify the studies to be included in the analysis. Any disagreements about inclusion were resolved by discussion and through arbitration by a third reviewer.

\section{Selection criteria}

We included articles that:

1. Participants included elderly people with a mean age of $\geq 60$ years who had chronic LBP;

2. For case-control study, participants included a control group of individuals healthy without LBP;

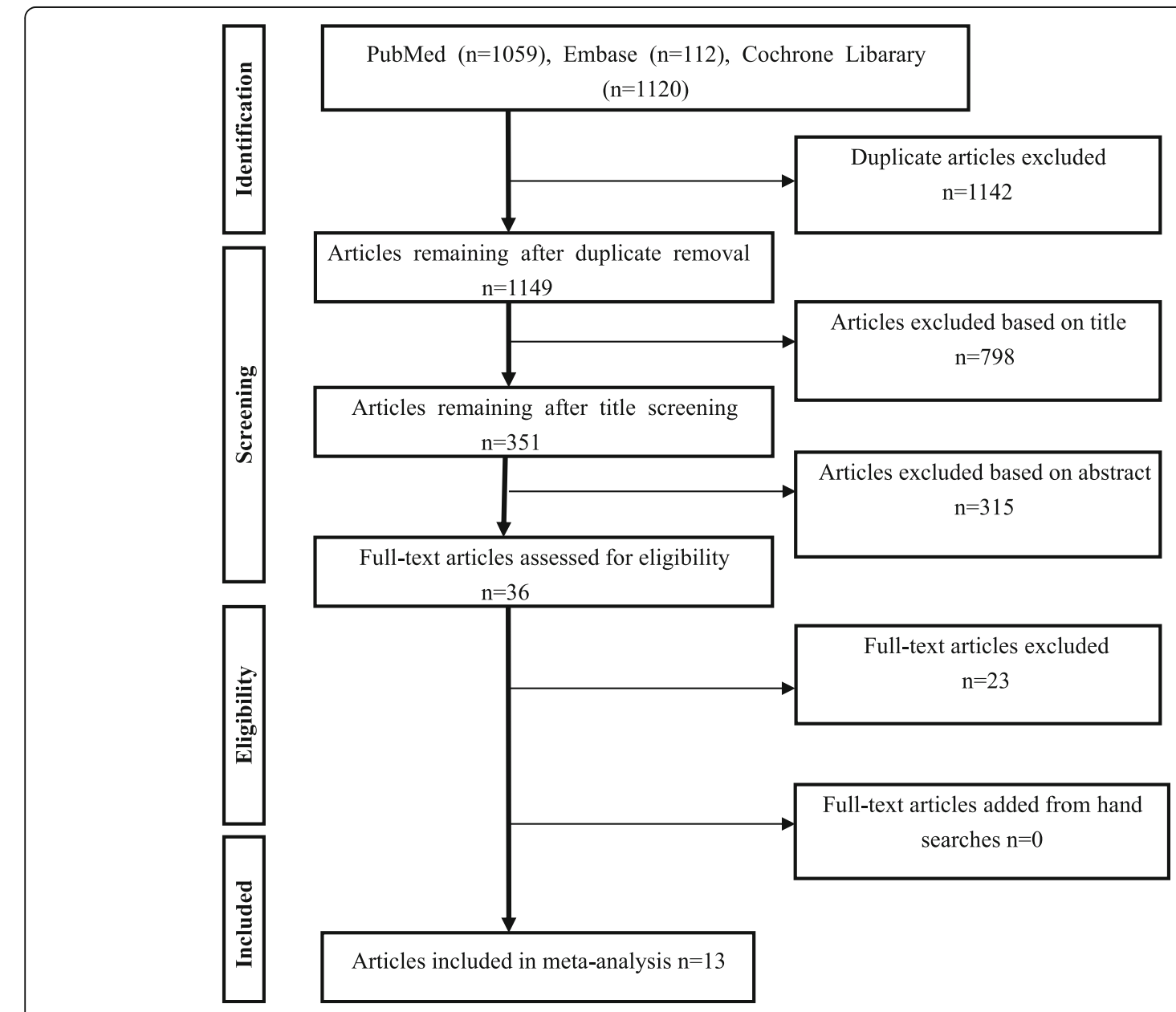

Fig. 1 PRISMA flow chart of the article screening and selection process 
3. Outcome measures included a measure of balance performance (e.g. balance and gait) that uses highly valid and reliable methods (such as static and dynamic posturographic analyses, centre of pressure [COP] analysis, centre of gravity analysis, and timed up and go test) to access their dynamic or static balance or balance performance. All the articles had to have been available in the English language and published in full within a peer-reviewed journal;

4. studies that scored $\geq 4$ on the Cross-sectional/Prevalence Study Quality scale (Agency for Healthcare Research and Quality, AHRQ) [20];
5. were written in English.

The following exclusion criteria were used:

1. Articles appeared only in abstract format or included insufficient detail to gauge study quality and extract results;

2. The articles were case reports or experimental studies.

\section{Study selection}

The search strategy is displayed in Fig. 1. Two reviewers independently screened all abstracts of articles potentially

Table 1 Basic characteristics of included case-control studies

\begin{tabular}{|c|c|c|c|c|c|c|c|c|}
\hline \multirow[t]{3}{*}{ References Design } & & \multicolumn{5}{|c|}{ Basic data of Participant } & \multirow[t]{3}{*}{ Balance task } & \multirow{3}{*}{$\begin{array}{l}\text { Outcome } \\
\text { measure } \\
\text { (balance } \\
\text { performance) }\end{array}$} \\
\hline & & \multicolumn{2}{|c|}{ LBP } & \multicolumn{2}{|l|}{ Health } & \multirow[t]{2}{*}{ Source of participants } & & \\
\hline & & $\begin{array}{l}\text { Age } \\
\text { (mean } \pm \\
\text { SD) }\end{array}$ & $\mathrm{N}$ & $\begin{array}{l}\text { Age } \\
\text { (mean } \pm \\
\text { SD) }\end{array}$ & $\mathbf{N}$ & & & \\
\hline Yi-Liang(2015) [21] & case-control & $60.5(4.1)$ & 13 & $59.7(3.0)$ & 13 & $\begin{array}{l}\text { local communities and } \\
\text { affiliated hospital }\end{array}$ & Single-leg standing & $\begin{array}{l}\text { TUG } \\
\text { STS }\end{array}$ \\
\hline Ito(2018) [22] & case-control & $75.5(5.1)$ & 28 & 73.7 (5.7) & 46 & $\begin{array}{l}\text { Department of Physical } \\
\text { Medicine } \\
\text { and Rehabitation }\end{array}$ & $\begin{array}{l}\text { eyes closed } \\
\text { Muscle Vibration }\end{array}$ & RPW \\
\hline Brumagne (2004) [23] & case-control & 63 & 10 & 63 & 10 & $\begin{array}{l}\text { Department of Physical } \\
\text { Medicine } \\
\text { and Rehabilitation }\end{array}$ & $\begin{array}{l}\text { 1. control (no vibration); } \\
\text { 2. bilateral vibration of } \\
\text { thetriceps surae tendons; } \\
\text { 3. bilateral vibration of the } \\
\text { Tibialis anterior tendons; } \\
\text { 4. bilateral vibration of the } \\
\text { Paraspinal muscle bellies }\end{array}$ & COP \\
\hline Ito(2017) [24] & case-control & $76.7(4.2)$ & 47 & $73.8(4.9)$ & 64 & $\begin{array}{l}\text { NationalCenter for } \\
\text { Geriatric and } \\
\text { Gerontology }\end{array}$ & Muscle Vibration & RPW \\
\hline Lee(2016) [25] & case-control & $64.5(5.7)$ & 30 & $66.2(4.5)$ & 26 & $\begin{array}{l}\text { University Hospital, } \\
\text { local communities, and } \\
\text { around the campus }\end{array}$ & Postural perturbation & COP \\
\hline Iversen(2009) [26] & case-control & $75.5(5.1)$ & 28 & 73.7 (5.7) & 46 & tertiary care spine center & static standing & $\begin{array}{l}\text { TUG } \\
\text { COP }\end{array}$ \\
\hline Kendall(2018) [27] & case-control & $82.4(4.6)$ & 24 & $81.1(4.3)$ & 19 & $\begin{array}{l}\text { a preventative } \\
\text { home visit } \\
\text { program }\end{array}$ & static standing & COP \\
\hline Sung(2017) [28] & case-control & $65.1(13.5)$ & 51 & $63.6(15)$ & 59 & community & walk & $\begin{array}{l}\text { gait } \\
\text { parameters }\end{array}$ \\
\hline Lihavainen(2010) [29] & case-control & $80.6(4.8)$ & 291 & $80.1(4.4)$ & 314 & $\begin{array}{l}\text { all the inhabitants of } \\
\text { thecity in Finland }\end{array}$ & $\begin{array}{l}\text { static standing } \\
\text { eyes open } \\
\text { eyes close } \\
\text { Feet together }\end{array}$ & $\mathrm{COP}$ \\
\hline Champagne(2012) [30] & case-control & $68.9(6.6)$ & 15 & $69.4(6.4)$ & 15 & local community & - & $\begin{array}{l}\text { TUG } \\
\text { One-leg } \\
\text { stance } \\
\text { Walking speed }\end{array}$ \\
\hline $\operatorname{Hicks(2018)~[31]~}$ & case-control & $69.3(6.7)$ & 54 & $71.1(6.8)$ & 54 & community & walk & $\begin{array}{l}\text { gait } \\
\text { parameters }\end{array}$ \\
\hline Silva(2016) [32] & case-control & $70.0(8)$ & 10 & $73.0(7)$ & 10 & local community & one-leg stance & COP \\
\hline Kato(2019) [33] & case-control & $77.4(4.2)$ & 21 & $78.1(4.4)$ & 17 & outpatient of hospital & one-leg standing & standing time \\
\hline
\end{tabular}




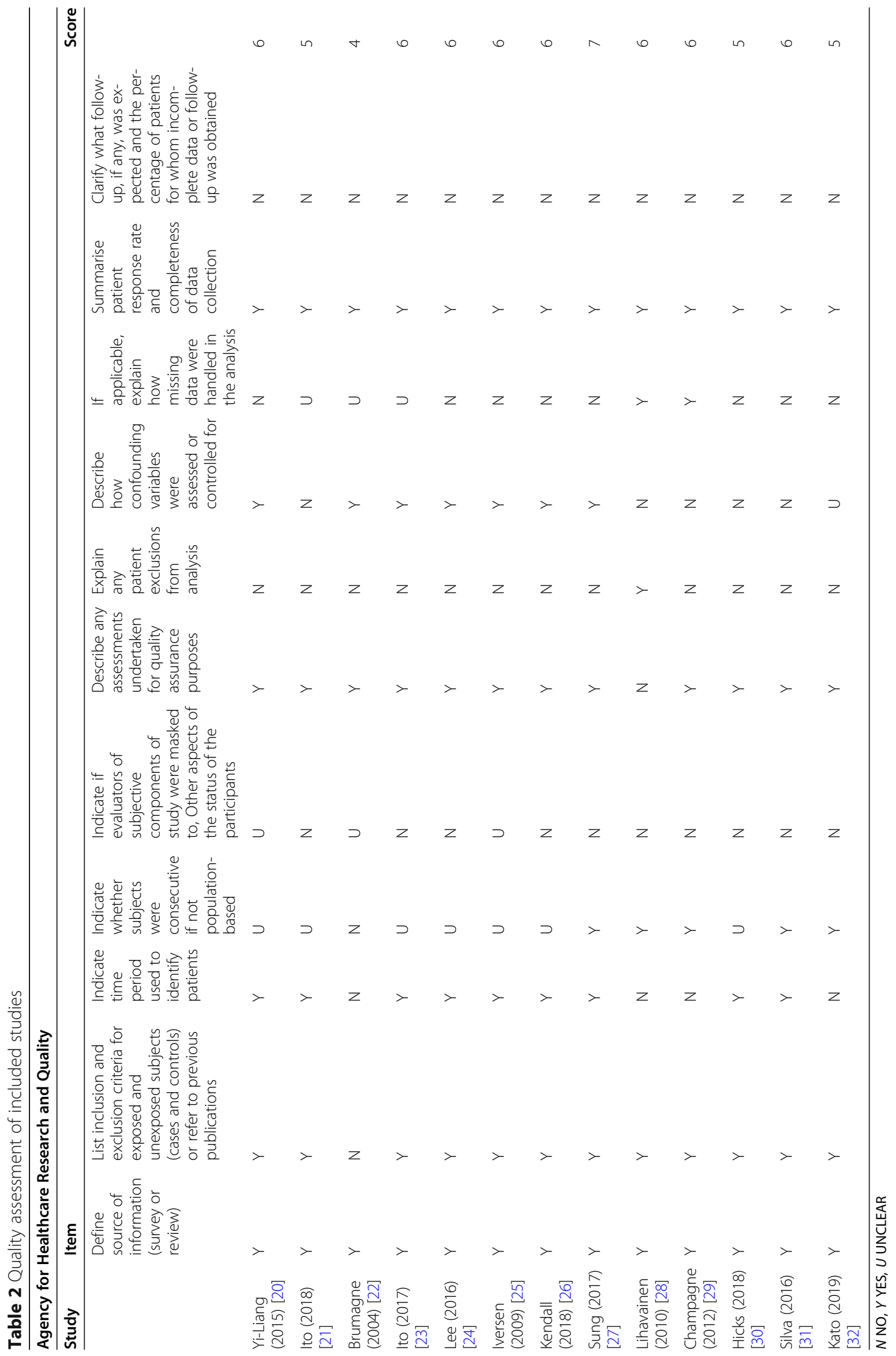


Table 3 One-leg stance

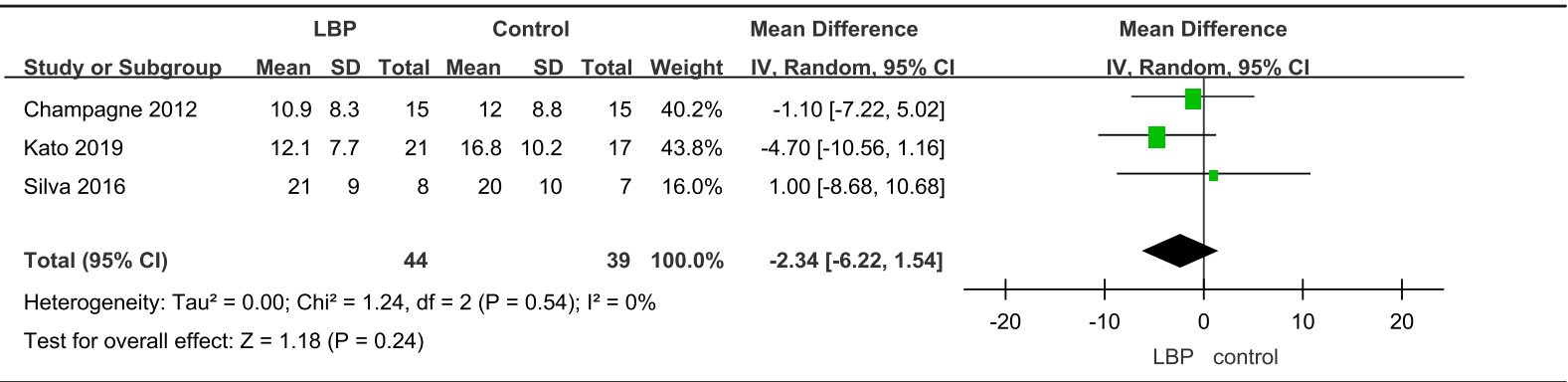

meeting the inclusion criteria. The full texts of those articles were subsequently reviewed. The reviewers then met with the entire review team and resolved any disagreements via consensus. The initial search yielded 2291 publications. Following the title and abstract screening, 35 full-text articles were retrieved. The full-text review was completed to determine final inclusion; 13 articles casecontrol studies [21-33] met the inclusion criteria.

\section{Quality assessment}

Quality was assessed using the Cross-sectional/Prevalence Study Quality (AHRQ) [20], which has 11 tests and a total score of 11 points. The two researchers independently evaluated all studies that met the inclusion criteria; there were no significant intergroup differences.

\section{Data extraction}

For each study that met the full inclusion and exclusion criteria, information regarding study design and outcome measures (e.g. COP, one-leg stance time) were extracted. The major results of each study focusing on balance function were briefly summarised. The meta-analysis data were collected from the results sections and tables of the manuscripts. The graphs were also used to extrapolate the data. If it was impossible to collect the data from the manuscript, the corresponding author of the manuscript was contacted twice before the study was excluded.

\section{Results}

\section{Search findings}

Figure 1 illustrates the search findings. The initial search yielded 2291 articles. After the two round of screening, 13 case-control studies that compared balance performance for elderly adults with LBP and healthy participants were remained. Data from the included studies are summarized in Table 1. Six studies use the COP parameters to evaluated the the balance performance of the participants ${ }^{[23,25.26,27,29,32]}$. Two studies use the relative proprioceptive weighting (RPW) [22, 24]. Three studies use the TUG test $[21,26]$. And three studies use the gait parameters [28, 30, 31].

In order to efficiently reduce the risks of bias, the studies had to score $\geq 4$ on AHRQ scale to be included in the review. The individual scores attained by the studies using the AHRQ scale are reported in Tables 2. The average AHRQ score for the 13 included studies was computed to be 5.6 out of 11 , indicating fair quality of the overall studies.

\section{Outcomes}

\section{One-leg stance}

A total of four articles used one-leg stance time to assess the balance function of patients with LBP and their healthy counterparts; however, one just calculated the number of people who stood on a single leg for $20 \mathrm{~s}$; therefore, we extracted data from three articles. No

Table 4 Centre of pressure area

\begin{tabular}{|c|c|c|c|c|c|c|c|c|c|c|c|c|}
\hline \multirow[b]{2}{*}{ Study or Subqroup } & \multicolumn{3}{|c|}{ LBP } & \multicolumn{3}{|c|}{ Control } & \multirow[b]{2}{*}{ Weight } & \multirow{2}{*}{$\begin{array}{l}\text { Mean Difference } \\
\text { IV, Random, } 95 \% \mathrm{Cl}\end{array}$} & \multirow{2}{*}{\multicolumn{4}{|c|}{$\begin{array}{c}\text { Mean Difference } \\
\text { IV, Random, } 95 \% \mathrm{Cl}\end{array}$}} \\
\hline & Mean & SD & Total & Mean & SD & Total & & & & & & \\
\hline Kendall 2018 & 412.38 & 297.02 & 24 & 416.42 & 526.77 & 19 & $0.0 \%$ & $-4.04[-269.04,260.96]$ & & & & \\
\hline Lee 2016 & 15.78 & 12.06 & 26 & 11.05 & 4.66 & 23 & $10.4 \%$ & $4.73[-0.28,9.74]$ & & & & \\
\hline Lee 2016 & 9.39 & 6.6 & 26 & 6.38 & 3.13 & 23 & $24.6 \%$ & $3.01[0.17,5.85]$ & & & & \\
\hline Lihavainen 2010 & 40.25 & 29.85 & 291 & 33.7 & 26.2 & 314 & $12.5 \%$ & $6.55[2.06,11.04]$ & & & & \\
\hline Lihavainen 2010 & 74.75 & 36.3 & 291 & 65.8 & 34.6 & 314 & $8.4 \%$ & $8.95[3.29,14.61]$ & & & & \\
\hline Lihavainen 2010 & 24.35 & 13.65 & 291 & 22.3 & 12.3 & 314 & $35.3 \%$ & $2.05[-0.03,4.13]$ & & & - & \\
\hline Lihavainen 2010 & 112.3 & 59.75 & 291 & 104.4 & 46.9 & 314 & $3.9 \%$ & $7.90[-0.70,16.50]$ & & & & \\
\hline Silva 2016 & 18 & 10 & 10 & 15 & 7 & 10 & $5.0 \%$ & $3.00[-4.57,10.57]$ & & & & \\
\hline Total $(95 \% \mathrm{Cl})$ & & & 1250 & & & 1331 & $100.0 \%$ & $3.98[2.23,5.73]$ & & & & \\
\hline \multicolumn{9}{|c|}{$\begin{array}{l}\text { Heterogeneity: } \operatorname{Tau}^{2}=1.14 ; \mathrm{Ch}^{2}=8.57, \mathrm{df}=7(\mathrm{P}=0.28) ; \mathrm{I}^{2}=18 \% \\
\text { Test for owerall effect: } Z=4.46(\mathrm{P}=0.00001)\end{array}$} & $\begin{array}{l}1 \\
-10\end{array}$ & -5 & $\operatorname{lLBP}^{5}$ & 10 \\
\hline
\end{tabular}


Table 5 Centre of pressure, anteroposterior velocity

\begin{tabular}{|c|c|c|c|c|c|c|c|c|c|c|c|c|}
\hline \multirow[b]{2}{*}{ Study or Subqroup } & \multicolumn{3}{|c|}{ LBP } & \multicolumn{2}{|c|}{ Control } & \multirow[b]{2}{*}{ Total } & \multirow[b]{2}{*}{ Weight } & \multirow{2}{*}{$\begin{array}{l}\text { Mean Difference } \\
\text { IV, Random, } 95 \% \mathrm{Cl}\end{array}$} & \multirow{2}{*}{\multicolumn{3}{|c|}{$\begin{array}{c}\text { Mean Difference } \\
\text { IV. Random, } 95 \% \mathrm{Cl}\end{array}$}} & \\
\hline & Mean & SD & Total & Mean & SD & & & & & & & \\
\hline Kendall 2018 & 18.71 & 10.87 & 24 & 14.79 & 7.21 & 19 & $4.1 \%$ & $3.92[-1.50,9.34]$ & & & & \\
\hline Lee 2016 & 0.31 & 0.1 & 26 & 0.26 & 0.11 & 23 & $21.5 \%$ & $0.05[-0.01,0.11]$ & & 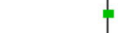 & 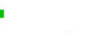 & \\
\hline Lihavainen 2010 & 15.05 & 6.2 & 291 & 13.2 & 5.4 & 314 & $19.1 \%$ & $1.85[0.92,2.78]$ & & & & \\
\hline Lihavainen 2010 & 11.45 & 5.9 & 291 & 10.3 & 4.9 & 314 & $19.4 \%$ & $1.15[0.28,2.02]$ & & & $\longrightarrow-$ & \\
\hline Lihavainen 2010 & 19.75 & 7.9 & 291 & 16.3 & 6.8 & 314 & $17.9 \%$ & $3.45[2.27,4.63]$ & & & & \\
\hline Lihavainen 2010 & 21.1 & 8 & 291 & 19.7 & 8 & 314 & $17.4 \%$ & $1.40[0.12,2.68]$ & & & & \\
\hline Silva 2016 & 41 & 18 & 10 & 45 & 19 & 10 & $0.5 \%$ & $-4.00[-20.22,12.22]$ & & & & \\
\hline Total $(95 \% \mathrm{Cl})$ & & & 1224 & & & 1308 & $100.0 \%$ & $1.59[0.37,2.80]$ & & & & \\
\hline \multicolumn{8}{|c|}{$\begin{array}{l}\text { Heterogeneity: } \operatorname{Tau}^{2}=1.78 ; \mathrm{Chi}^{2}=58.39, \mathrm{df}=6(\mathrm{P}<0.00001) ; \mathrm{I}^{2}=90 \% \\
\text { Test for overall effect: } Z=2.56(\mathrm{P}=0.01)\end{array}$} & & -4 & $\begin{array}{cc}-2 & 1 \\
\text { control } & \end{array}$ & LBP & 4 \\
\hline
\end{tabular}

significant difference was noted between the two groups (Table 3).

\section{COP area}

A total of four studies used COP parameters to measure balance performance, which was recognised as a valid and reliable method. The larger the COP area was, the worse the balance performance was. Older adults with LBP had a longer path length and larger area of COP movements than older adults without LBP (Table 4).

\section{COP anteroposterior velocity, mediolateral velocity, and anteroposterior range}

A total of four studies used COP sway velocity parameters to measure motor control (Tables 5 and 6), while two studies used COP sway range parameters to measure motor control (Table 7). The higher the COP sway velocity and the longer path length in the anteroposterior direction was, the more unstable the individual was. The three parameters also demonstrated that older adults with LBP would have higher velocity and larger COP movements than older adults without LBP.

\section{Gait (speed) and TUG}

A total of three studies used the gait test (Table 8) and two studies used the TUG (Table 9) to compare the dynamic balance between individuals with LBP and those without LBP. The result showed that, compared to healthy individuals, patients with LBP walked more slowly and needed more time to complete the TUG test.

\section{Relative proprioceptive weighting}

Two studies compared the RPW between the two groups but found no significant intergroup difference (Table 10).

Outcomes measures, risk bias of the studies included in the meta-analysis and sensitivity analysis

Using STATA software to assess the study biases and sensitivity analysis (Table 11), the sensitivity results suggested that our meta-analysis results are relatively stable.

\section{Discussion}

This meta-analysis, which identified 13 case-control studies that compared balance performance for elderly adults with LBP and healthy participants. The qualities of all the case-control studies were moderate. The risk of bias was assessed for each article using the Cochrane Collaboration recommendations, the sensitivity results suggested that our meta-analysis results seem to be stable.

To our knowledge, this is the first systematic review and meta-analysis to focus on LBP and balance performance in elderly people. This systematic review aimed to estimate the effect of LBP on balance performance in elderly people. Our results demonstrated that elderly people with LBP have poorer balance performance than those without LBP. With the rapidly aging society, the proportion of elderly patients with chronic LBP is increasing annually, which lead to bad moods, functional inactivity, a decrease in quality of life, and an increase in

Table 6 Centre of pressure, mediolateral velocity

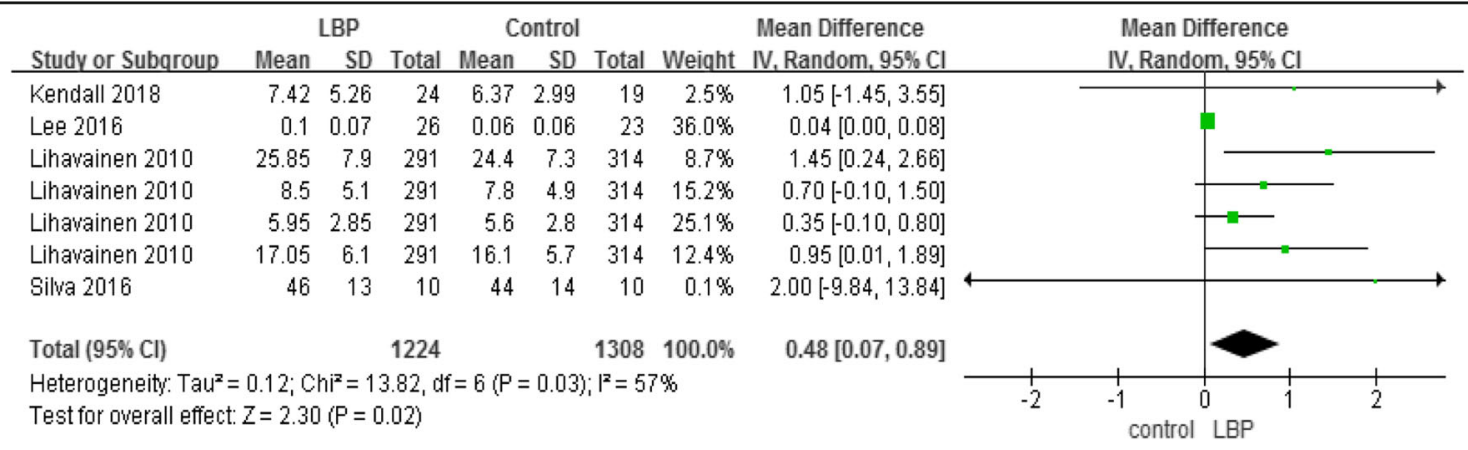


Table 7 Centre of pressure, anteroposterior range

\begin{tabular}{|c|c|c|c|c|c|c|c|c|c|c|c|c|}
\hline \multirow[b]{2}{*}{ Study or Subqroup } & \multicolumn{3}{|c|}{ LBP } & \multicolumn{2}{|c|}{ Control } & \multicolumn{3}{|r|}{ Mean Difference } & \multirow{2}{*}{\multicolumn{3}{|c|}{$\begin{array}{c}\text { Mean Difference } \\
\text { IV, Random, } 95 \% \mathrm{Cl}\end{array}$}} & \\
\hline & Mean & $\mathrm{SD}$ & Total & Mean & $\mathrm{SD}$ & Total & Weight & IV, Random, $95 \% \mathrm{Cl}$ & & & & \\
\hline Brumagne 2004 & 7.2 & 3.2 & 10 & 5 & 3.1 & 10 & $46.4 \%$ & $2.20[-0.56,4.96]$ & & & + & \\
\hline Brumagne 2004 & 10.2 & 4.1 & 10 & 5.9 & 5.2 & 10 & $21.0 \%$ & $4.30[0.20,8.40]$ & & & & \\
\hline Lee 2016 & 21.95 & 8.25 & 26 & 17.01 & 6.82 & 23 & $19.9 \%$ & $4.94[0.72,9.16]$ & & & & \\
\hline Lee 2016 & 29.19 & 8.64 & 26 & 23.92 & 10.05 & 23 & $12.7 \%$ & $5.27[-0.01,10.55]$ & & & & \\
\hline Total (95\% Cl) & & & 72 & & & 66 & $100.0 \%$ & $3.58[1.69,5.46]$ & & & & \\
\hline $\begin{array}{l}\text { Heterogeneity: } \mathrm{Tau}^{2} \\
\text { Test for owerall effec }\end{array}$ & $\begin{array}{l}0.00 ; \mathrm{C} \\
\mathrm{z}=3.72\end{array}$ & $\begin{array}{l}\mathrm{h}^{2}=1 \\
\langle\mathrm{P}=0\end{array}$ & $\begin{array}{l}87, \mathrm{df}= \\
1.0002)\end{array}$ & & $0.60) ; 1^{2}$ & $=0 \%$ & & & $\frac{1}{-10}$ & -5 & $\begin{array}{c}0 \\
\text { control LBP }\end{array}$ & $\frac{+}{10}$ \\
\hline
\end{tabular}

fall risk. [34]. It is necessary to provide effective intervention measures to improve elderly peoples' quality of life and reduce the economic losses and physical and emotional trauma caused by chronic LBP.

The aging process results in changes in the central nervous system, peripheral nervous system, and the musculoskeletal system [35, 36]. Pain itself has a wide range of effects on motor function [37]. People who experience chronic pain display changes in motor patterns, exercise coordination, and the ability to maintain stability in response to external disturbances. possible that older adults with LBP should be subjected to different assessments and interventions than younger adults to account for the differences in therapeutic approaches and treatment outcomes. Given the age disparities in LBP people, in addition to solving the pain issue, it is important to focus on the balance performance of older individuals. As we all know, balance control with age is among the major risk factors for falls, which is a difficult problem that the world faces, especially as the population continues to age [38].

Table 8 Gait speed

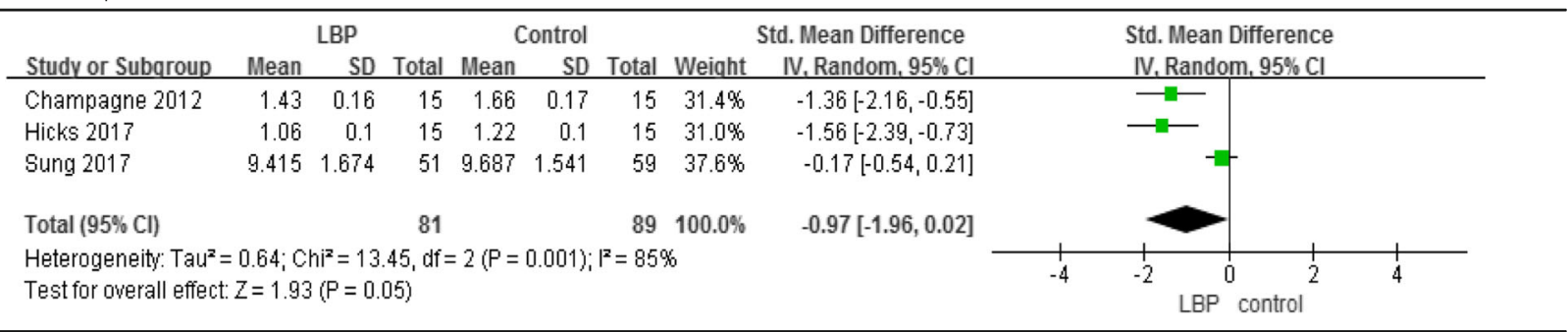

Pain induces spinal motility restrictions, lumbar proprioceptive losses, weakening of lower-extremity sensory feedback, and trunk muscle weakness and atrophy [26, 28, 29, 32]. Thus, when aging is combined with LBP, balance performance becomes worse. However, almost $90 \%$ of articles to date focused on young and middle-aged people. It is conceivable that conditions associated with younger and middle-aged people are more optimistic regardless of the balance performance or responsive to treatment. It is also
Poor balance performance in elderly people with LBP means they could not perform accurate movements and ambulation $[39,40]$, which in turn affected their physical activities. In the present study, TUG, one-leg stance, postural sway, and gait are reliable and valid fall-risk assessments [41-44], poor outcomes on the TUG and postural sway tests may indicate an increased risk of falling that could lead to disastrous consequences. Problems with balance performance were also reportedly associated with fall risk [45]. Physical therapists in the clinical

Table 9 Timed up and go test

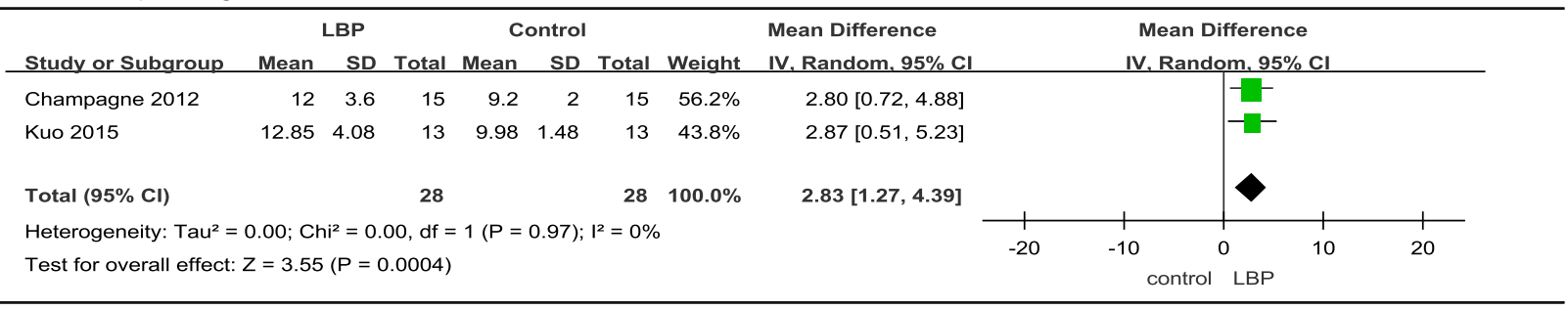


Table 10 Relative proprioceptive weighting

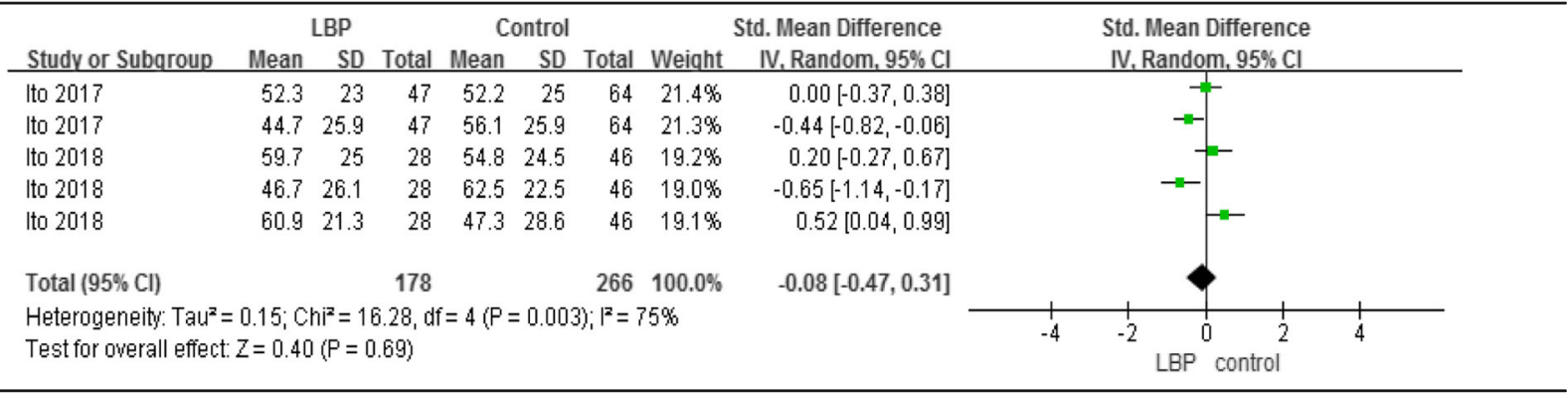

setting should be aware of an increased risk of falling for their patients with LBP.

There is some evidence that LBP impacts the equilibrium of older individuals. However, only one study in this review assessed reactive balance control, which assessed the postural responses to a suddenly released pulling force in older adults with LBP [24]. The results showed older adults with LBP had poorer postural responses in delayed reaction, larger displacement, higher velocity, longer path length, and greater COP sway area compared to the older healthy controls. The outcome parameters assessed in Lee et al's [24] study were similar to those used in present study. Sudden postural perturbations are very common during everyday life, such as pulling an object that might suddenly move or open, poorer reactive balance control is important to maintain balance in the sudden postural perturbation, which could reduce the falling risk. Besides the reactive balance control, it is also very common for postural tasks to be accompanied with cognitive tasks (e.g., making a telephone call while walking) in daily life. Understanding of the effects of dual tasks on static and dynamic balance performance among older individuals with LBP could help reduce the occurrence of falls for the elderly people. However, none study assessed the effect of dual tasks on balance performance in older individuals with LBP. Future studies must focus more on this issue, especially on motor performance or balance function in these patients. The results of this review depended on the outcome measures examined in the reviewed articles, and the small sample sizes may have limited the power of our findings. Therefore, future research should include

Table 11 Outcomes measures, risk bias of the studies included in the meta-analysis and sensitivity analysis

\begin{tabular}{|c|c|c|c|c|}
\hline outcomes & References & Design & $P$ value & Egger's test ( $P$ value) \\
\hline One-leg stance & $\begin{array}{l}\text { Champagne(2012) [30] } \\
\text { Silva(2016) [32] } \\
\text { Kato(2019) [33] }\end{array}$ & case-control & $P=0.24$ & 0.365 \\
\hline COP area & $\begin{array}{l}\text { Lee(2016) [25] } \\
\text { Kendall(2018) [27] } \\
\text { Lihavainen(2010) [29] } \\
\text { Silva(2016) [32] }\end{array}$ & case-control & $P<0.01$ & 0.273 \\
\hline COP AP velocity & $\begin{array}{l}\text { Lee(2016) [25] } \\
\text { Kendall(2018) [27] } \\
\text { Lihavainen(2010) [29] } \\
\text { Silva(2016) [32] }\end{array}$ & case-control & $P=0.01$ & 0.929 \\
\hline COP ML velocity & $\begin{array}{l}\text { Lee(2016) [25] } \\
\text { Kendall(2018) [27] } \\
\text { Lihavainen(2010) [29] } \\
\text { Silva(2016) [32] }\end{array}$ & case-control & $P=0.02$ & 0.161 \\
\hline COP AP range & $\begin{array}{l}\text { Brumagne(2004) [23] } \\
\text { Lee(2016) [25] }\end{array}$ & case-control & $P<0.01$ & 0.184 \\
\hline Gait & $\begin{array}{l}\text { Sung(2017) [28] } \\
\text { Hicks(2018) [31] } \\
\text { Champagne(2012) [30] }\end{array}$ & case-control & $P=0.05$ & 0.037 \\
\hline TUG & $\begin{array}{l}\text { Yi-Liang(2015) [21] } \\
\text { Iversen(2009) [26] } \\
\text { Champagne(2012) [30] }\end{array}$ & case-control & $P<0.01$ & 0.317 \\
\hline RPW & $\begin{array}{l}\text { Ito(2018) [22] } \\
\text { Ito(2017) [24] }\end{array}$ & case-control & $P=0.69$ & 0.682 \\
\hline
\end{tabular}


adequate sample sizes and must be combined with myoelectric and neural electrical activity and gait analyses to evaluate dynamic-static equilibrium and reactive balance, which could better reflect the effect of the central nervous system on peripheral control.

\section{Study limitations}

This review included only case-control studies. Furthermore, the present review did not incorporate nonEnglish studies. This may limit the validity of our findings and must be taken into consideration when interpreting its overall generalizability. The limited number of case-control studies did not allow a subgroup metaanalysis. However, we achieved the main aim of our review, which was to estimate the effect of LBP on balance performance in elderly people.

\section{Conclusion}

In summary, the study results indicate evidence in favour of a negative effect of LBP on balance performance in elderly people with LBP. Future studies should focus on the mechanisms and effective interventions for abnormal balance control in elderly people with LBP.

\section{Abbreviations}

LBP: Low back pain; COP: Centre of pressure; RPW: Relative proprioceptive weighting; AP: Anteroposterior; ML: Mediolateral; TUG: Timed up and go test; STS: Sit-to-stand test; AHRQ: Cross-sectional/Prevalence Study Quality; PRIS MA: Systematic Reviews and Meta-analysis

\section{Acknowledgements}

Not applicable.

\section{Authors' contributions}

All authors were involved in drafting the article or revising it critically for important intellectual content and all authors approved the final version to be published.

\section{Funding}

Not applicable.

Availability of data and materials

Not applicable.

\section{Declarations}

Ethics approval and consent to participate

Not applicable.

\section{Consent for publication}

All authors approved the final version to be published.

\section{Competing interests}

The authors declare that they have no competing interests.

\section{Author details}

${ }^{1}$ Department of Rehabilitation Medicine, The First Affiliated Hospital, Sun Yat-sen University, Zhongshan Road, Guangzhou 510080, Guangdong Province, China. ${ }^{2}$ Pathophysiology Department of Basic Medical Collage, Jilin University, Changchun, China.
Received: 4 January 2021 Accepted: 17 May 2021

Published online: 05 June 2021

\section{References}

1. Nations, B.U. Department of Economic and Social Affairs. World Population Ageing 2009. Popul Dev Rev. 2011;37.

2. Bressler HB, Keyes WJ, Rochon PA, Badley E. The prevalence of low back pain in the elderly. A systematic review of the literature. Spine (Phila Pa 1976). 1999;24(17):1813-9. https://doi.org/10.1097/00007632-19990901000011.

3. Podichetty VK, Mazanec DJ, Biscup RS. Chronic non-malignant musculoskeletal pain in older adults: clinical issues and opioid intervention. Postgrad Med J. 2003;79(937):627-33. https://doi.org/10.1136/pmj.79.937.62 7.

4. Edmond SL, Felson DT. Prevalence of back symptoms in elders. J Rheumatol. 2000;27(1):220-5.

5. Hoy D, Bain C, Williams G, March L, Brooks P, Blyth F, et al. A systematic review of the global prevalence of low back pain. Arthritis Rheum. 2012; 64(6):2028-37. https://doi.org/10.1002/art.34347.

6. Molton IR, Terrill AL. Overview of persistent pain in older adults. Am Psychol. 2014;69(2):197-207. https://doi.org/10.1037/a0035794.

7. Hartvigsen J, Hancock MJ, Kongsted A, Louw Q, Ferreira ML, Genevay S, et al. What low back pain is and why we need to pay attention. Lancet. 2018:391(10137):2356-67. https://doi.org/10.1016/S0140-6736(18)30480-X

8. Chen Q, Hayman LL, Shmerling RH, Bean JF, Leveille SG. Characteristics of chronic pain associated with sleep difficulty in older adults: the maintenance of balance, independent living, intellect, and zest in the elderly (MOBILIZE) Boston study. J Am Geriatr Soc. 2011;59(8):1385-92. https://doi.org/10.1111/j.1532-5415.2011.03544.x.

9. Hodges PW, Richardson CA. Inefficient muscular stabilization of the lumbar spine associated with low back pain. A motor control evaluation of transversus abdominis. Spine (Phila Pa 1976). 1996;21(22):2640-50. https:// doi.org/10.1097/00007632-199611150-00014.

10. Nies N, Sinnott PL. Variations in balance and body sway in middle-aged adults. Subjects with healthy backs compared with subjects with low-back dysfunction. Spine (Phila Pa 1976). 1991;16(3):325-30. https://doi.org/10.1 097/00007632-199103000-00012.

11. Piscitelli D. Motor rehabilitation should be based on knowledge of motor control. Arch Physiother. 2016;6:5. Published 2016 Jun 23. https://doi.org/1 0.1186/s40945-016-0019-z.

12. Hodges PW, Richardson CA. Altered trunk muscle recruitment in people with low back pain with upper limb movement at different speeds. Arch Phys Med Rehabil. 1999;80(9):1005-12. https://doi.org/10.1016/s0003-9993 (99)90052-7

13. Tsao H, Galea MP, Hodges PW. Reorganization of the motor cortex is associated with postural control deficits in recurrent low back pain. Brain. 2008;131(Pt 8):2161-71. https://doi.org/10.1093/brain/awn154.

14. Tsao H, Druitt TR, Schollum TM, Hodges PW. Motor training of the lumbar paraspinal muscles induces immediate changes in motor coordination in patients with recurrent low back pain. J Pain. 2010;11(11):1120-8. https:// doi.org/10.1016/j.jpain.2010.02.004.

15. Stelmach GE, Teasdale N, Di Fabio RP, Phillips J. Age related decline in postural control mechanisms. Int J Aging Hum Dev. 1989;29(3):205-23. https://doi.org/10.2190/KKPO-W3Q5-6RDN-RXYT.

16. Chan DCL, Wong TWL, Zhu FF, Cheng Lam C, Young WR, Capio CM, et al. Investigating changes in real-time conscious postural processing by older adults during different stance positions using electroencephalography coherence. Exp Aging Res. 2019;45(5):410-23. https://doi.org/10.1080/0361 $073 \times .2019 .1664450$

17. Duarte M, Sternad D. Complexity of human postural control in young and older adults during prolonged standing. Exp Brain Res. 2008;191(3):265-76. https://doi.org/10.1007/s00221-008-1521-7.

18. Muraki S, Akune T, Oka H, En-Yo Y, Yoshida M, Nakamura K, et al. Prevalence of falls and the association with knee osteoarthritis and lumbar spondylosis as well as knee and lower back pain in Japanese men and women. Arthritis Care Res (Hoboken). 2011;63(10):1425-31. https://doi.org/10.1002/acr.20562.

19. Shamseer $L$, Moher D, Clarke $M$, et al. Preferred reporting items for systematic review and meta-analysis protocols (PRISMA-P) 2015: elaboration and explanation [published correction appears in BMJ. 2016 Jul 21;354: i4086]. BMJ. 2015;350:g7647 Published 2015 Jan 2. https://doi.org/10.1136/ bmj.g7647. 
20. Stephenson J. AHRQ director sets course for Agency's health services research. JAMA. 2016:316(16):1632-4. https://doi.org/10.1001/jama.2016.12 702.

21. Kuo YL, Huang KY, Chiang PT, Lee PY, Tsai YJ. Steadiness of Spinal Regions during Single-Leg Standing in Older Adults with and without Chronic Low Back Pain. PLoS One. 2015;10(5):e0128318. Published 2015 May 29. https:// doi.org/10.1371/journal.pone.0128318.

22. Ito T, Sakai Y, Morita Y, et al. Proprioceptive Weighting Ratio for Balance Control in Static Standing Is Reduced in Elderly Patients With Non-Specific Low Back Pain [published correction appears in Spine (Phila Pa 1976). 2020 May 15;45(10):E606]. Spine (Phila Pa 1976). 2018;43(24):1704-9. https://doi. org/10.1097/BRS.0000000000002817.

23. Brumagne $S$, Cordo $P$, Verschueren S. Proprioceptive weighting changes in persons with low back pain and elderly persons during upright standing. Neurosci Lett. 2004;366(1):63-6. https://doi.org/10.1016/j.neulet.2004.05.013.

24. Ito T, Sakai Y, Yamazaki K, Igarashi K, Sato N, Yokoyama K, et al. Proprioceptive change impairs balance control in older patients with low back pain. J Phys Ther Sci. 2017;29(10):1788-92. https://doi.org/10.1589/ jpts.29.1788

25. Lee PY, Lin SI, Liao YT, et al. Postural Responses to a Suddenly Released Pulling Force in Older Adults with Chronic Low Back Pain: An Experimental Study. PLoS One. 2016;11(9):e0162187. Published 2016 Sep 13. https://doi. org/10.1371/journal.pone.0162187.

26. Iversen MD, Kale MK, Sullivan JT Jr. Pilot case control study of postural sway and balance performance in aging adults with degenerative lumbar spinal stenosis. J Geriatr Phys Ther. 2009;32(1):15-21. https://doi.org/10.1519/0013 9143-200932010-00004

27. Kendall JC, Hvid LG, Hartvigsen J, Fazalbhoy A, Azari MF, Skjødt M, et al. Impact of musculoskeletal pain on balance and concerns of falling in mobility-limited, community-dwelling Danes over 75 years of age: a crosssectional study. Aging Clin Exp Res. 2018;30(8):969-75. https://doi.org/10.1 007/s40520-017-0876-7.

28. Sung PS, Zipple JT, Danial P. Gender differences in asymmetrical limb support patterns between subjects with and without recurrent low back pain. Hum Mov Sci. 2017;52:36-44. https://doi.org/10.1016/j.humov.2017.01. 002.

29. Lihavainen K, Sipilä S, Rantanen T, Sihvonen S, Sulkava R, Hartikainen S. Contribution of musculoskeletal pain to postural balance in communitydwelling people aged 75 years and older. J Gerontol A Biol Sci Med Sci. 2010;65(9):990-6. https://doi.org/10.1093/gerona/glq052.

30. Champagne A, Prince F, Bouffard V, Lafond D. Balance, falls-related selfefficacy, and psychological factors amongst older women with chronic low Back pain: a preliminary case-control study. Rehabil Res Pract. 2012;2012 430374. https://doi.org/10.1155/2012/430374.

31. Hicks GE, Sions JM, Coyle PC, Pohlig RT. Altered spatiotempora characteristics of gait in older adults with chronic low back pain. Gait Posture. 2017:55:172-6. https://doi.org/10.1016/j.gaitpost.2017.04.027.

32. da Silva RA, Vieira ER, Carvalho CE, Oliveira MR, Amorim CF, Neto EN. Agerelated differences on low back pain and postural control during one-leg stance: a case-control study. Eur Spine J. 2016;25(4):1251-7. https://doi.org/1 0.1007/s00586-015-4255-9.

33. Kato S, Murakami H, Demura $S$, et al. Abdominal trunk muscle weakness and its association with chronic low back pain and risk of falling in older women. BMC Musculoskelet Disord. 2019;20(1):273. Published 2019 Jun 3. https://doi.org/10.1186/s12891-019-2655-4.

34. Fehlings MG, Tetreault $L$, Nater $A$, et al. The aging of the global population: the changing epidemiology of disease and spinal disorders. Neurosurgery. 2015;77(Suppl 4):S1-5. https://doi.org/10.1227/NEU.0000000000000953.

35. Burns ER, Stevens JA, Lee R. The direct costs of fatal and non-fatal falls among older adults - United States. J Saf Res. 2016;58:99-103. https://doi. org/10.1016/j.jsr.2016.05.001.

36. Deandrea S, Lucenteforte E, Bravi F, Foschi R, La Vecchia C, Negri E. Risk factors for falls in community-dwelling older people: a systematic review and meta-analysis. Epidemiology. 2010;21(5):658-68. https://doi.org/10.1097/ EDE.0b013e3181e89905.

37. Lee JK, Desmoulin GT, Khan AH, Park EJ. Comparison of 3D spinal motions during stair-climbing between individuals with and without low back pain. Gait Posture. 2011:34(2):222-6. https://doi.org/10.1016/j.gaitpost.2011.05.002.

38. Scheffer AC, Schuurmans MJ, van Dijk N, van der Hooft T, de Rooij SE. Fear of falling: measurement strategy, prevalence, risk factors and consequences among older persons. Age Ageing. 2008;37(1):19-24. https://doi.org/10.1 093/ageing/afm169.

39. Nelson-Wong E, Poupore K, Ingvalson S, Dehmer K, Piatte A, Alexander S, et al. Neuromuscular strategies for lumbopelvic control during frontal and sagittal plane movement challenges differ between people with and without low back pain. J Electromyogr Kinesiol. 2013;23(6):1317-24. https:// doi.org/10.1016/j.jelekin.2013.08.011

40. Crosbie J, Nascimento DP, Filho Rde F, Ferreira P. Do people with recurrent back pain constrain spinal motion during seated horizontal and downward reaching? Clin Biomech (Bristol, Avon). 2013;28(8):866-72. https://doi.org/1 0.1016/j.clinbiomech.2013.09.001.

41. Kojima G, Masud T, Kendrick D, et al. Does the timed up and go test predict future falls among British community-dwelling older people? Prospective cohort study nested within a randomised controlled trial. BMC Geriatr. 2015; 15:38. Published 2015 Apr 3. doi:https://doi.org/10.1186/s12877-015-0039-7

42. Dohrn IM, Hagströmer M, Hellenius ML, Ståhle A. Gait speed, quality of life, and sedentary time are associated with steps per day in communitydwelling older adults with osteoporosis. J Aging Phys Act. 2016;24(1):22-31. https://doi.org/10.1123/japa.2014-0116.

43. Thomas JI, Lane JV. A pilot study to explore the predictive validity of 4 measures of falls risk in frail elderly patients. Arch Phys Med Rehabil. 2005; 86(8):1636-40. https://doi.org/10.1016/j.apmr.2005.03.004

44. Tucker MG, Kavanagh JJ, Morrison S, Barrett RS. What are the relations between voluntary postural sway measures and falls-history status in community-dwelling older adults? Arch Phys Med Rehabil. 2010;91(5):750-8. https://doi.org/10.1016/j.apmr.2010.01.004.

45. Kim BJ, Robinson CJ. Postural control and detection of slip/fall initiation in the elderly population. Ergonomics. 2005;48(9):1065-85. https://doi.org/10.1 080/00140130500071028.

\section{Publisher's Note}

Springer Nature remains neutral with regard to jurisdictional claims in published maps and institutional affiliations.
Ready to submit your research? Choose BMC and benefit from:

- fast, convenient online submission

- thorough peer review by experienced researchers in your field

- rapid publication on acceptance

- support for research data, including large and complex data types

- gold Open Access which fosters wider collaboration and increased citations

- maximum visibility for your research: over $100 \mathrm{M}$ website views per year

At BMC, research is always in progress.

Learn more biomedcentral.com/submissions 